\title{
Nolong.in: an android based incident notification application with push notification technology
}

\author{
Arthur Bachtiar Gunawan, Seng Hansun, Marcel Bonar Kristanda \\ Department of Informatics, Universitas Multimedia Nusantara, Indonesia
}

\begin{tabular}{l}
\hline \hline Article Info \\
\hline Article history: \\
Received Jan 5, 2018 \\
Revised Jun 29, 2018 \\
Accepted Sep 13, 2018 \\
\hline
\end{tabular}

Keywords:

Android

Firebase cloud messaging

Incident notification

Push notification

Safety

\begin{abstract}
In driving, the most important thing to be considered is safety. The incident problem can happen anytime and anywhere without anyone knowing it before, especially in Cikarang where the level of incident is quite high. It is very important for the public community to act and respond quickly at the time on and around the occurring incident. Nolong.in application is an exact solution because it can send real time notifications to its users. This response is meant to assist individuals who have been using Nolong.in to help other users who need urgent help when the time of incident in order to prevent unwanted situations. In this research, push notification method has been implemented by using Firebase Cloud Messaging (FCM). The result of the research is the notification click ratio is $90.91 \%$ and the click time is 1 minute and 27 seconds. Based on the questionnaires' results given to the community conclude that Nolong.in application is very beneficial for Gojek Cikarang community's safety.
\end{abstract}

Copyright $(2019$ Institute of Advanced Engineering and Science. All rights reserved.

\section{Corresponding Author:}

Seng Hansun,

Department of Informatics,

Universitas Multimedia Nusantara,

J1. Scientia Boulevard, Gading Serpong, Tangerang, Banten-15811 Indonesia.

Email: hansun@umn.ac.id

\section{INTRODUCTION}

There are so many road accidents and incidents that commonly experienced by car and motorcycle drivers. Road accidents can be caused by bad driving behaviour, like driving too fast and recklessly, driving under alcohol influence, breaching the vehicles safe distance, etc. [1]. Other accidents can be caused by bad and uncontrolled road signs and facilities, such as misplaced and unnecessary speed breakers and bumpy roads as had been reported by Kiran, et al. [2]. Sharma and Shah [3], Shariff, et al. [4], and Fernandez, et al. [5] had also worked and published papers related to the road accident detection and prevention. Meanwhile, road incidents such as street robberies, road constructions, etc. can also lead to severe damage for the drivers. There are some researches that focus on road incidents to improve knowledge in accident or incident mechanism analysis as can be seen on the works of Serre, et al. [6] and Gakis, et al. [7].

Bekasi is an area with the highest criminality in West Java. Susy Susilawati as the Head of Regional Office of the Ministry of Justice and Human Rights (Kemenkumham) said that Class II Penitentiary (Lapas Kelas II) Bulak Kapal dan Class III Penitentiary (Lapas Kelas III) in Cikarang-Bekasi, could take around 40 people from different cases [8].

In Bekasi, especially Cikarang, there are some types of criminality in road that often happen, one of them is violent robbery. Data from Central Bureau of Statistics (Badan Pusat Statistik) Kota Bekasi said that in 2015, there were 34 cases of this type of criminality [9].

Gunawan had conducted a research in 2017 about how online motorcycle taxi's drivers take care of this kind of problem [10]. Gunawan said that when incident happen to a driver, he/she will tell his/her friends 
in the social group chat that they are having an incident [10]. But, when the incident occured, they cannot tell immediately in the social group chat. Therefore, Gunawan made a panic button device that can be used to tell friends that they are having an incident. This device uses Bluetooth technology to connect to smartphone and Arduino microcontroller.

Push notification used to send emergency notification to responders quickly and easily when there's an emergency [11]. When it becomes difficult to communicate in an emergency, the fastest and easiest way to communicate would be via mobile messaging using push notification [12]. Push notification is used to send notification to responders even when the app does not open or active [13]. Based on previous researches about panic button and push notification, notification incident application for community of GoJek Cikarang will be build on Android platform.

\section{THEORETICAL BASIS}

\subsection{Push notification}

Push notification is a small and short message used by mobile application to tell users about new event [14]. Push notification is an important feature in mobile computing service and had been implemented in many mobile applications [15]. Push notification service in mobile had become an important service to send content to user [13]. Using push notification, message can still be send to end users even the app is not running [13]. It solved problem from smartphone that doesn't have feature like multi-tasking and battery saver, also when the app is not running [13]. Information that users need can be sent immediately without the needs to request to the system [16].

Since the development of Internet of Things (IoT), so many devices that connect to Internet, like sensor, wearable devices, and household appliances. Notification can be push to this device and initiate by this device to track environment/body/tool or providing context, like location. The convergence of mobile with IoT also create new challenges on how system can handle mixed push channels that created by M2M (Machine to Machine) communication and human interactions, also allow effective interaction between human and IoT devices.

Push method needs two softwares that know what each other needs. Software for client that know how to send request, send, store, and display data. Software for server that know request from client, so server can send the data [16]. Push method implementation schema as shown in Figure 1.

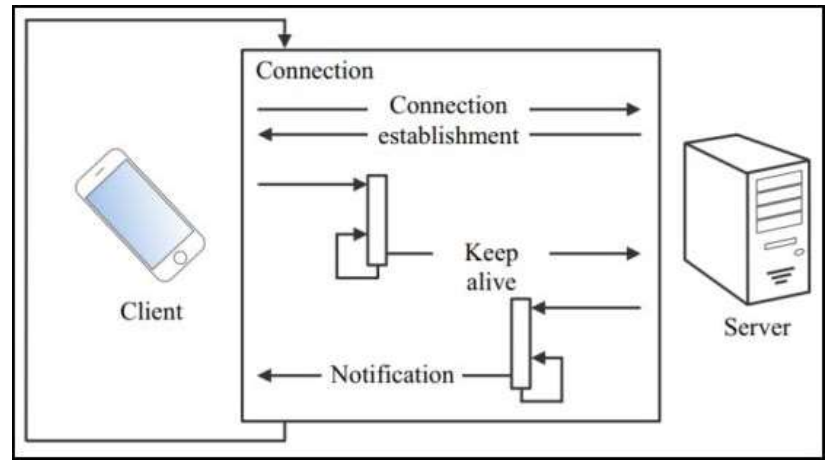

Figure 1. Push method implementation schema

\subsection{Firebase cloud messaging}

Firebase Cloud Messaging (FCM), the successor of Google Cloud Messaging (GCM), is a solution for sending message between platform which is reliably and with no cost. Using FCM, client can be notified when there are new data that ready to be synchronized. FCM also allow notification message sending to each user in a specific segment [17].

Figure 2 shows FCM architecture. Sending notification message from server to client can be done in two ways, notifications console GUI and trusted environment. Using console is very effective for trial or highly targeted marketing and user engagement. Through this way, there's no coding needed, we only need to input the required data. To send notification through trusted environment can be done using Admin SDK and HTTP/XMPP.

Application needs to extend FirebaseMessagingService to get notification from Firebase. This 
service will handle all notification that this application got. For sending notification to specific device, application needs to extend FirebaseInstanceIdService to get a registration token. This token is used to differentiate every application that installed on every device.

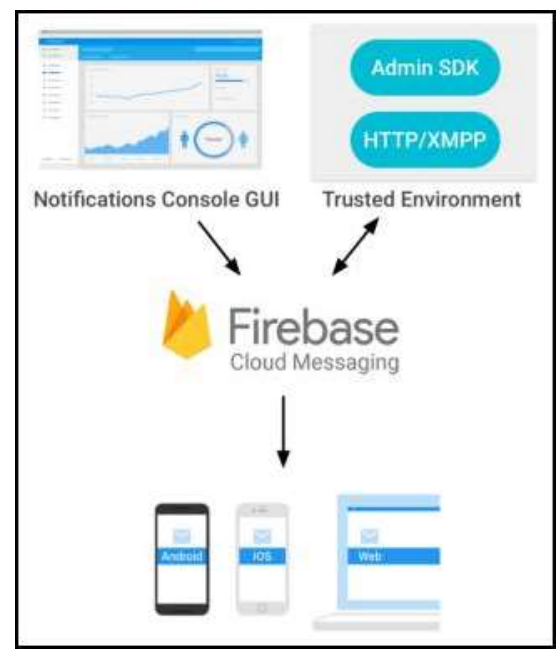

Figure 2. FCM architecture

\subsection{Google maps distance matrix API}

Google Maps Distance Matrix API is a service that provides distance and travel time from origins to destinations according to recommended route between two location points. To access this API, HTTP is needed to request the desired URL using origins, destinations, and an API key. Figure 3 is an example of URL to access Distance Matrix API using Washington, DC as origin and New York City, NY as destionation address [18]. Figure 4 is an example of Google Maps Distance Matrix API response. This response contains the distance, duration, and address location between the origins and destinations.

$$
\begin{aligned}
& \text { https://maps.googleapis.com/maps/api/distancematrix/json?units=imperial\&origin } \\
& \text { s=Washington,DC\&destinations=New }+ \text { York }+ \text { City,NY\&key }=\text { YOUR_API_KEY }
\end{aligned}
$$

Figure 3. URL request Distance Matrix API example

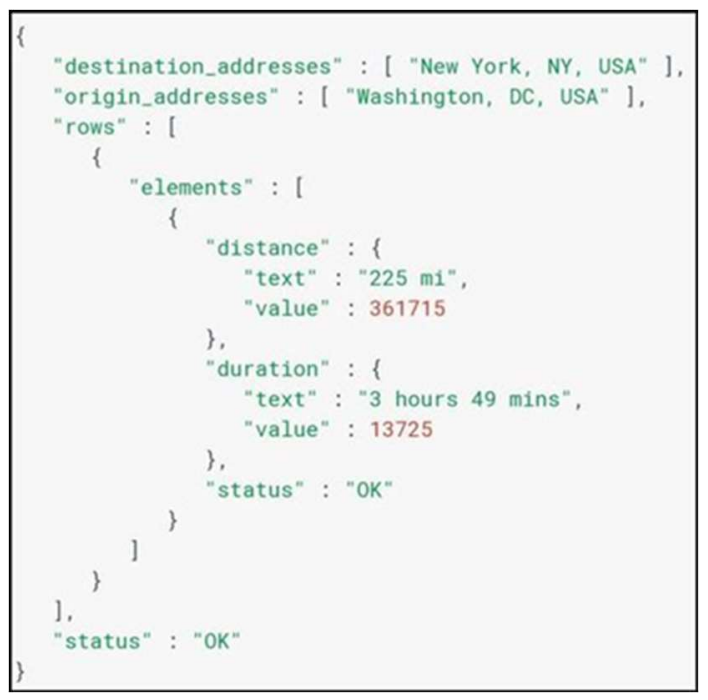

Figure 4. Distance Matrix API response example 


\subsection{Click ratio and click time}

Click time is used to get user reaction from notification. In Shirazi, et al. [19], they used click time by measuring total click of notification on every mobile application category [19]. In this research, click ratio will be used on every notification that user got. To calculate click ratio, total click of notification will be divided by total notification that had been sent.

Click time is used to get difference between obtained notification and clicked notification. The result of Shirazi's research is that category system has the fastest click time and messenger in second place. The conclusion from Shirazi's research about click time is fifty percent of user interaction with notification, happens in thirty seconds after notification is obtained. In this research, click time will be used to calculate difference between obtained and clicked notification. Then, this total click time will be divided by total notification that had been sent.

\subsection{User experience questionnaire}

User experience is thorough experience that consists of every aspect from user experience with a product or service [20]. User Experience Questionnaire (UEQ) is an assessment that can be done quickly to get user experience from interactive product [21]. Main objective of UEQ is to get quick and immediate count from user experience with a product [22]. Sugiyono said that according to Roscoe, minimum proper sample is 30 samples [23]. Therefore, the minimum respondent that will fill the questionnaire are 30 people. In this research, UEQ will be used to get user experience with this product. UEQ consist of 26 scalable items from six elements: Attractiveness, Perspicuity, Efficiency, Dependability, Stimulation, and Novelty [24].

Attractiveness is a general impression of the product, is the user like or not. There are six items in this scale, annoying/enjoyable, good/bad, unlikeable/pleasing, unpleasant/pleasant, attractive/unattractive, and friendly/unfriendly. Perspicuity is the easiness to know how to use this product. There are four items in this scale, not understandable/understandable, easy to learn/difficult to learn, complicated/easy, clear/confusing. Efficiency is the easiness to use this product quickly and efficiently. There are four items on this scale, fast/slow, inefficient/efficient, impractical/practical, and organized/cluttered. Dependability is how user feels the interaction within system, is the interaction secure and meets expectation. There are four items in this scale, unpredictable/predictable, obstructive/supportive, and secure/not secure, meets expectation/does not meet expectation. Stimulation is the interest of using the product, does the user want to use this product in the future or not. There are four items in this scale, valuable/inferior, boring/exciting, not interesting/interesting, motivating/demotivation. Novelty is user's opinion about creativity of the product. There are four items in this scale, creative/dull, inventive/conventiontal, usual/leading edge, conservative/innovative.

According to UEQ handbook [24], UEQ use scale from +3 for positive statement and -3 for negative statement. After user finish fill the questionnaire, all of the value from each point wil be calculated to get the average value. If the value is between -0.8 and 0.8 , the scale is considered as neutral. If the value is -0.8 , the scale is considered as bad and if above 0.8 , the scale is considered as good.

\subsection{Nolong.in device}

Nolong.in device is a device that made by Gunawan in 2017 (Figure 5) [10]. This device has a button that can be use to send signal to the application to notify that user is having an incident. The components of this device are Arduino Pro Mini 3.3V as the main component to execute every command, Bluetooth HC-05 to connect device with application, lithium battery 3.7V with 2,200 mAh, and a switch for turning on and off the device.

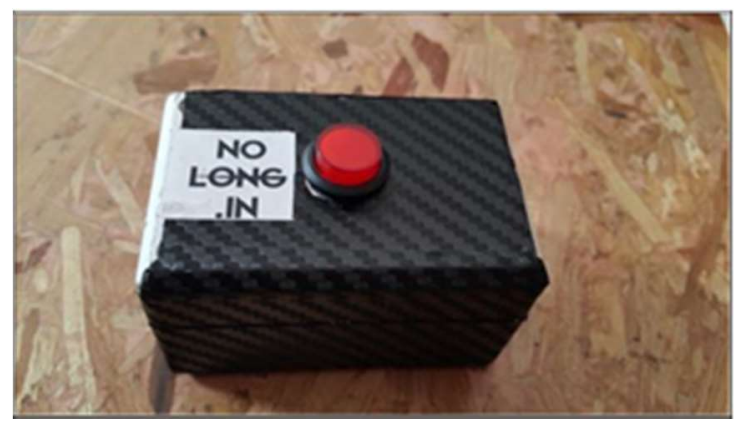

Figure 5. Nolong.in device 


\section{RESEARCH METHODOLOGY AND APPLICATION DESIGN}

\subsection{Research methodology}

Before starting the research project, we determined the research metdohology that will be used. These are the methodology research in this research:

a. Literature review

Literature review used for knowing concept of push notification and Firebase Cloud Messaging, so that it can implemented in this application. The study is done by reading references from many sources, like thesis, papers, journals, and other sources. This process is done throughout research, design, and building the application.

b. Designing application

Designing application is started with designing the work flow of the application. The application work flow is drawn using flowchart.

c. Building application

After design of the application is done, next step is programming the application. Implementing push notification to the application which is used for sending notification to helpers when incident is happening is done in this phase. The application will be build using Java, PHP, and MySQL.

d. Testing

In this process, click ratio and click time will be used for measuring notification effectiveness that user got. Testing process will be done in one week.

e. Evaluating

In evaluating process, data from UEQ, click ratio, and click time will be analyzed in quantitative form, so that it can show respond when respondent got a notification.

\subsection{Testing and evaluation scenario}

Testing is done in one week, where on the first until third day drivers that have the device must press the button when an incident happened to them. On the fourth until seventh day, drivers that have device instructed to press the button so it can send a false notification to get the data. For drivers that received the notification, they had instructed to click the notification by assuming that the person who sent the notification is experiencing an incident. On the last day, drivers of this community were given a questionnaire for fill in. After done with the testing, evaluation is done by measuring click ratio and click time according to the notification's data, also by evaluating the questionnaire's results data.

\subsection{Application design}

Figure 6 is the flowchart of overall system. The application can be opened through two ways, first is by opening it directly and second is through notification. Then, it will display splash screen and get into Authentication process. This process is used to authenticate user that want to use this application. After that, in Choose Bluetooth Device process, user will choose the Bluetooth connection of the device, so it can send signal from device to application and application to device.

After successfully connected, in Store Firebase Reg ID process, the Firebase registration token will be stored in database. In Settings process, user can set the radius of sending notification and logout from the application. Send Notification process is the process for sending notification to other users. The last process is Show Active and History process. This process is used for showing any user that needs help and user that has been helped by a user.

\subsection{System architecture}

Figure 7 is the system architecture of Nolong.in. When user pressed a panic button in the device, application will send the needed data to Firebase to sending notification to PHP web service. This data consists of user's Firebase registration ID and the message. Then, PHP web service will send the notification to Firebase and store it in database. After that, Firebase will send the notification to other targeted client and the data will be displayed in client application from database. 


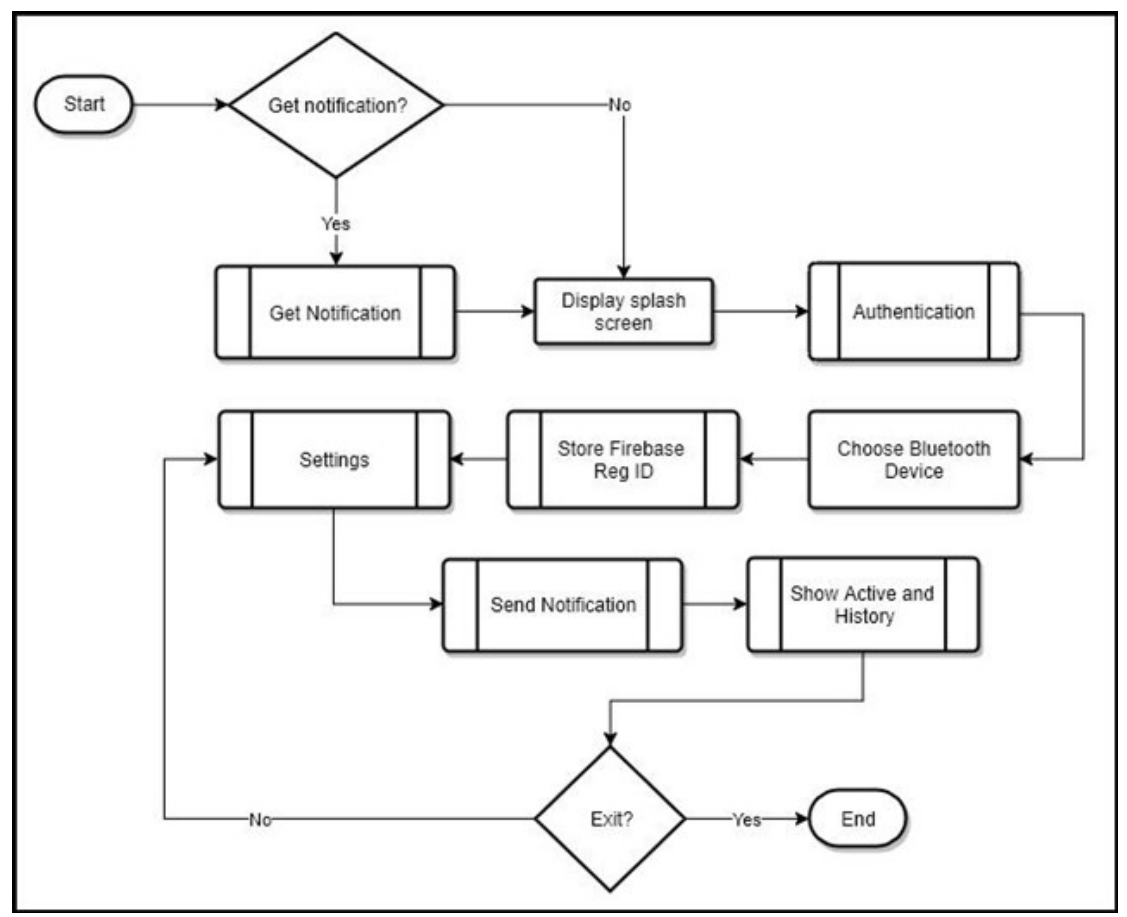

Figure 6. Application flowchart

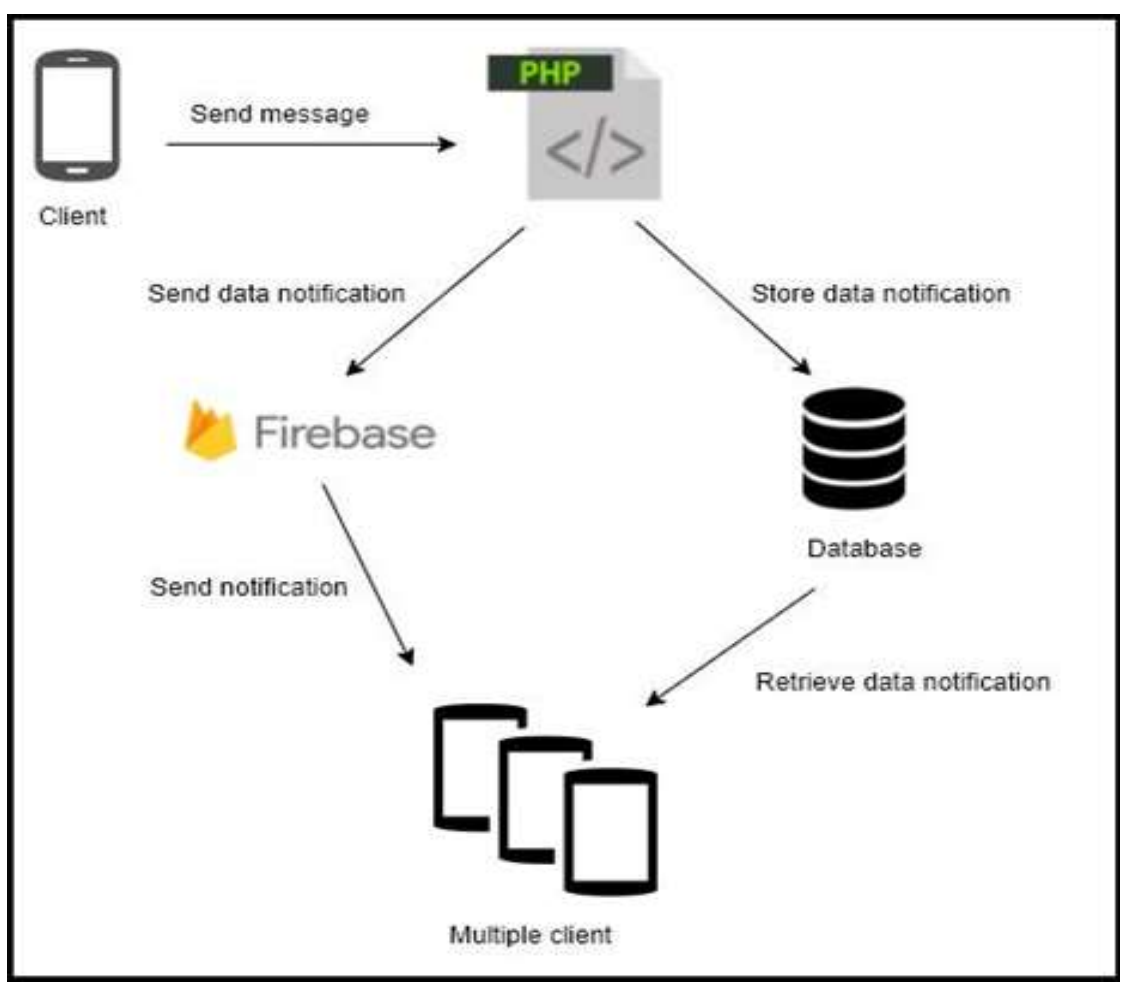

Figure 7. System architecture

\section{RESULTS AND DISCUSSION}

4.1. Application results

Figure 8 is the interface implementation of Get Notification process. In this interface, there are notification's title and message. Figure 9 is the interface implementation of Send Notification process. There 
are three parts in this interface. In Part 1, there is a dialog box that appears when button in the device is pressed. In Part 2, there's a button to indicate that this user has been helped by other users. In Part 3, there's a dialog box that appear when button in Part 2 is pressed. This dialog box is used as user confirmation that he/she has been helped.

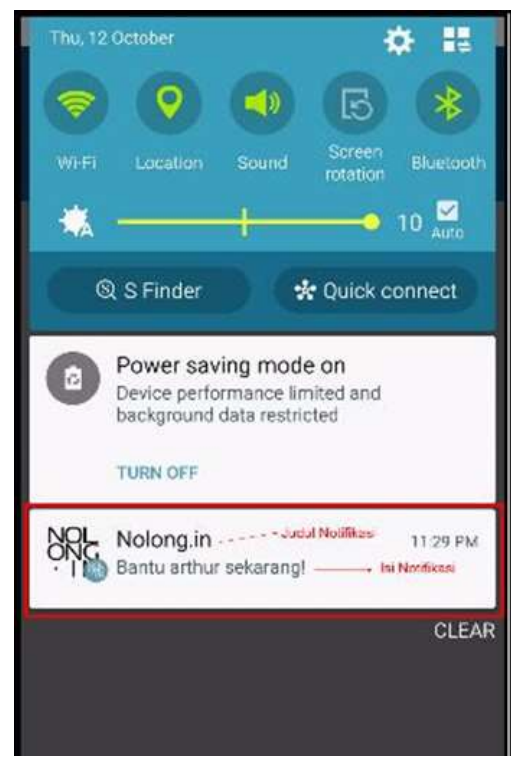

Figure 8. Interface implementation of Get Notification Process
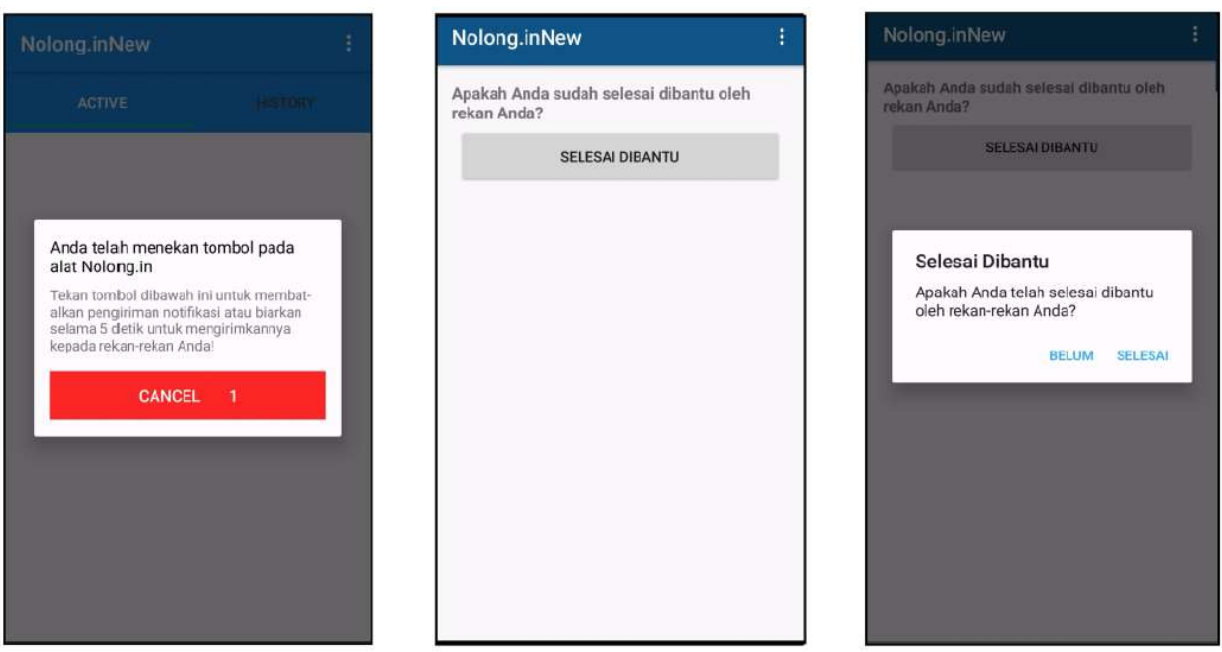

Figure 9. Interface implementation of Send Notification Process

Figure 10 is the interface implementation of Show Active and History process. In this process, there are seven parts. Part 1 is the interface when there are users that need helps. Part 2 is the dialog box that appears when button BANTU (HELP) in Part 1 is pressed. Part 3 is the interface after user pressed BANTU in Part 2. Part 4 is the dialog box that appears when button SAMPAI (ARRIVE) in Part 3 is pressed. Then, in Part 5 there's a list of nearest hospitals. Part 6 is the interface when user has done in helping other user. The last part is appeared when user click SELESAI MEMBANTU (HELP FINISHED) in Part 6. 

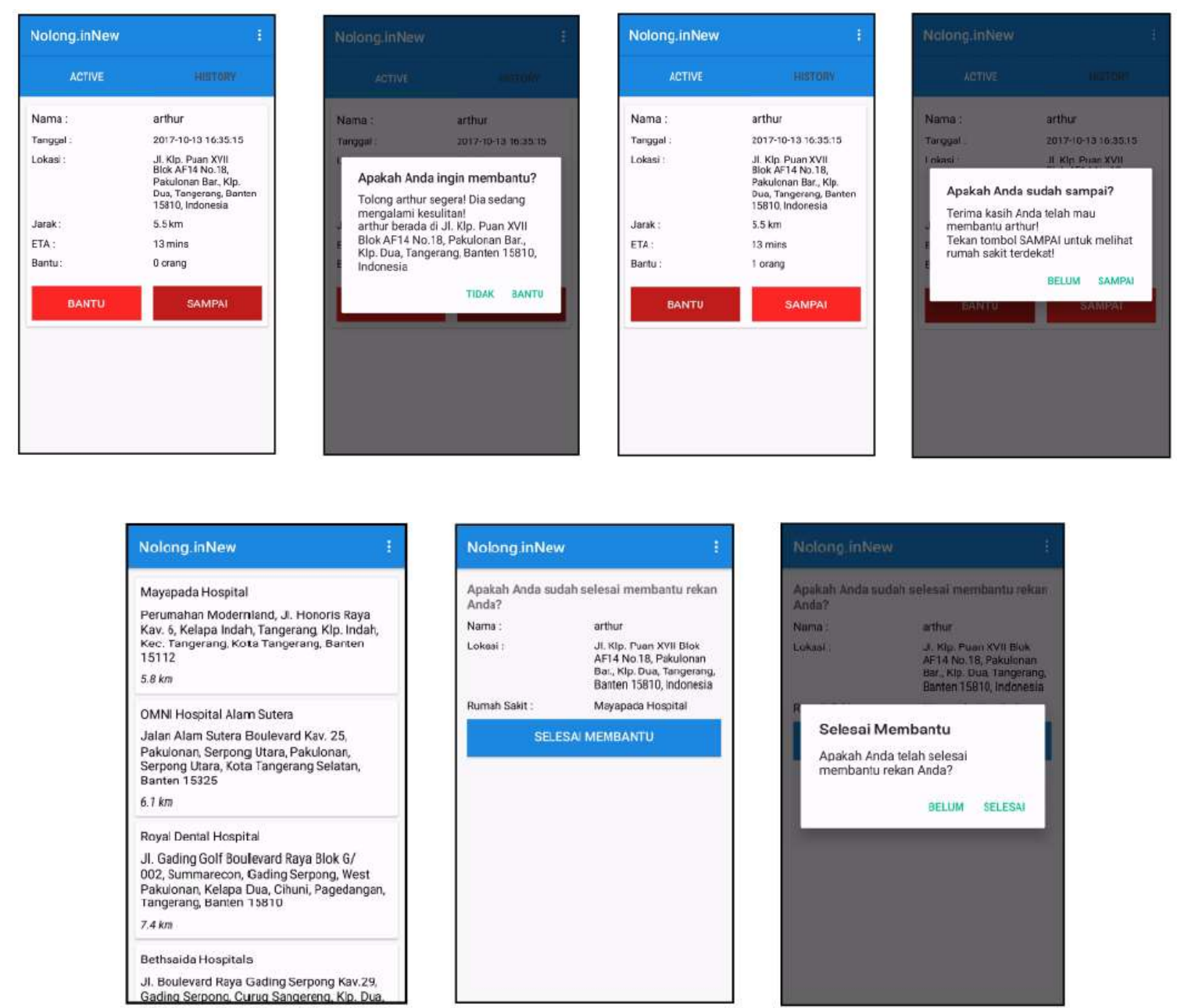

Figure 10. Interface implementation of Show Active and History Process

\subsection{Data sampling}

In this process, data sampling is done by using Convenience Sampling technique. This sampling technique is used because sample was obtained when helding Focus Group Discussion (FGD) with the community of GoJek Cikarang and has been explained about Nolong.in device. Data sampling is done in one week with 32 data samples. On the last day, samples were given questionnaire based on UEQ. In UEQ handbook, it is eligible to remove some scales inside the questionnaire [25]. Therefore, in this research, Novelty scale is not used because an application using panic button device is not a new product as Nimb has already implemented it before.

\subsection{Testing results}

After going through collecting data in one week, notification's data and questionnaire's data was got. Table 1 indicates the result of the click ratio. This application's click ratio is 0.9019 or $90.19 \%$, because when some users got the notification, they are either delivering passengers or goods, so they didn't know that there are notifications from other users that need helps. To get the click time, total differentiate time between got and clicked notification, and total notification clicked is needed. Table 2 indicates the result of the click time. This application's click time is 87 seconds or 1 minute and 27 seconds.

Figure 11 is the graph of respondent's opinion about notification sending when incident happens in the forms of speediness. From this data, 44\% respondent gave rating Sangat Setuju (Very Agree), 41\% respondent gave rating Setuju (Agree), and 15\% respondent gave rating Cukup Setuju (Quite Agree). 
Table 1. Click Ratio Result

\begin{tabular}{ccc}
\hline $\begin{array}{c}\text { Total Clicked } \\
\text { Notification }\end{array}$ & $\begin{array}{c}\text { Total Notification } \\
\text { Sent }\end{array}$ & Click Ratio \\
\hline 46 & 51 & 0.9019 \\
\hline
\end{tabular}

Table 2. Click Time Result

\begin{tabular}{ccc}
\hline $\begin{array}{c}\text { Total Differentiate } \\
\text { Time }\end{array}$ & $\begin{array}{c}\text { Total Clicked } \\
\text { Notification }\end{array}$ & Click Time \\
\hline 3,985 & 46 & 87 \\
\hline
\end{tabular}

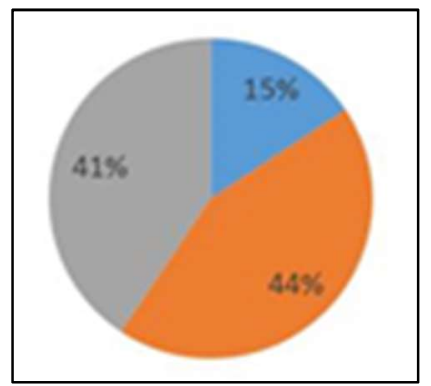

Figure 11. Graph of user's opinion on Notification Sending when Incident Happens (Blue: Quite Agree, Grey: Agree, Orange: Very Agree)

According to the result of both measurements, it can be deduced that Nolong.in is responded quickly by community of GoJek Cikarang. This also supports the result from the questionnaire's data which indicates that notification can be sent quickly, because there is no respondent that gave rating below Cukup Setuju (Quite Agree). Besides notification is responded quickly, we can also deduce that this community willing to help others that need help.

These are the UEQ results from the respondent. There are five scales that will be tested, i.e. Attractiveness, Perspicuity, Efficiency, Dependability, and Stimulation. In analyzing the data, Likert scale is used, where Very Agree option has value 3, Agree option has value 2, Quite Agree option has value 1, Neutral has value 0 , and so on. Therefore, the maximum value from the average and total average are 3 and the minimum are -3 . According to five scales that had been tested on Table 3-7, it can be concluded that Nolong.in has a good response from the users.

Table 3. Attractiveness Scale Result

\begin{tabular}{lcc}
\hline \multicolumn{1}{c}{ Good Item / Bad Item } & Value & Average \\
\hline Enjoyable / Annoying & 2.4375 & \\
Good / Bad & 2.28125 & \\
Pleasing / Unlikeable & 2.28125 & 2.28125 \\
Pleasant / Unpleasant & 2.28175 & \\
Attractive / Unattractive & 2.25 & \\
Friendly / Unfriendly & 2.28175 & \\
\hline
\end{tabular}

Table 5. Efficiency Scale Result

\begin{tabular}{lcc}
\hline \multicolumn{1}{c}{ Good Item / Bad Item } & Value & Average \\
\hline Fast / Slow & 2.28125 & \\
Efficient / Inefficient & 2.5 & 2.3671875 \\
Practical / Impractical & 2.3125 & \\
Organized / Cluttered & 2.375 & \\
\hline
\end{tabular}

Table 4. Perspicuity Scale Result

\begin{tabular}{lcc}
\hline \multicolumn{1}{c}{ Good Item / Bad Item } & Value & Average \\
\hline Understandable / Not Understandable & 2.59375 & \\
Easy To Learn / Difficult To Learn & 2.625 & \multirow{2}{*}{2.5078125} \\
Easy/ Complicated & 2.40625 & \\
Clear / Confusing & 2.40625 & \\
\hline
\end{tabular}

Table 6. Dependability Scale Result

\begin{tabular}{lcc}
\hline \multicolumn{1}{c}{ Good Item / Bad Item } & Value & Average \\
\hline Predictable / Unpredictable & 2.84375 & \\
Supportive / Obstructive & 2.78125 & \\
Secure / Not Secure & 2.78125 & 2.6640625 \\
Meets Expectations / Doesn't Meet & 2.25 & \\
Expectations & & \\
\hline
\end{tabular}

Table 7. Stimulation Scale Result

\begin{tabular}{lcc}
\hline \multicolumn{1}{c}{ Good Item / Bad Item } & Value & Average \\
\hline Valuable / Inferior & 2.84375 & \\
Exciting / Boring & 2.59375 & 2.6171875 \\
Interesting / Not Interesting & 2.34375 & \\
Motivating / Demotivating & 2.6875 & \\
\hline
\end{tabular}

Tables 8-10 are used to analyze user sentiment on the using of Nolong.in in safety driving that will be further analyzed in Table 11 and 12. In Table 11, average column is obtained from the total value that user gave in incident experienced and length of work based on Nolong.in benefit, then divided by total user that

Nolong.in: An Android Based Incident Notification Application with Push... (Arthur Bachtiar Gunawan) 
scored. Total average column is obtained just like average, but only in incident experienced. In Table 12 , average column and total average column are obtained just like average column in Table 11, but only based on the length of work. The results from Table 11 and Table 12 show that driver with at least had experienced one incident and worked more than 1 year feels that Nolong.in is very beneficial for safety driving.

Table 8. Result of Work's Length as GoJek Driver

\begin{tabular}{ccc}
\hline Question & Option & Result \\
\hline How long you work as GoJek driver? & $<6$ months & $31.3 \%$ \\
How long you work as GoJek driver? & 6 months - 1 year & $21.9 \%$ \\
How long you work as GoJek driver? & $1-2$ years & $21.9 \%$ \\
How long you work as GoJek driver? & $>$ 2 years & $25 \%$ \\
\hline
\end{tabular}

Table 9. Result of How Many Incidents have been Experienced

\begin{tabular}{ccc}
\hline Question & Option & Result \\
\hline How many incidents you have been experienced during work as GoJek driver? & Never & $43.8 \%$ \\
How many incidents you have been experienced during work as GoJek driver? & $1-3$ times & $43.8 \%$ \\
How many incidents you have been experienced during work as GoJek driver? & $4-7$ times & $12.5 \%$ \\
How many incidents you have been experienced during work as GoJek driver? & $8-10$ times & $0 \%$ \\
How many incidents you have been experienced during work as GoJek driver? & $>10$ times & $0 \%$ \\
\hline
\end{tabular}

Table 10. Result of Nolong.in Benefit

\begin{tabular}{lc}
\hline Option & Result \\
\hline Very Agree & 27 \\
Agree & 5 \\
Quite Agree & 0 \\
Neutral & 0 \\
Quite Disagree & 0 \\
Disagree & 0 \\
Very Disagree & 0 \\
\hline
\end{tabular}

Table 11. Result of User Sentiment through Nolong.in Benefit based on Incident Experience

\begin{tabular}{llcc}
\hline Incident Experienced & Length of Work & Average & Total Average \\
\hline Never & $<6$ months & 2.4286 & \\
Never & 6 months -1 year & 2.5 & 2.6429 \\
Never & $1-2$ years & 3 & \\
Never & $>2$ years & 3 & \\
$1-3$ times & $<6$ months & 3 & 3 \\
$1-3$ times & 6 months -1 year & 3 & \\
$1-3$ times & $1-2$ years & 3 & \\
$1-3$ times & $>2$ years & 3 & 3 \\
$4-7$ times & $<6$ months & 3 & \\
$4-7$ times & 6 months -1 year & 3 & \\
$4-7$ times & $1-2$ years & 3 & \\
$4-7$ times & $>2$ years & 3 & \\
\hline
\end{tabular}

Table 12. Result of User Sentiment through Nolong.in Benefit based on Length of Work

\begin{tabular}{llcc}
\hline Length of Work & Incident Experienced & Average & Total Average \\
\hline$<6$ months & Never & 2.4286 & 2.6 \\
$<6$ months & $1-3$ times & 3 & \\
6 months -1 year & Never & 2.5 & 2.8571 \\
6 months -1 year & $1-3$ times & 3 & \\
1 - 2 years & Never & 3 & 3 \\
1 - 2 years & $1-3$ times & 3 & \\
1 - 2 years & $4-7$ times & 3 & 3 \\
$>2$ years & Never & 3 & \\
$>2$ years & $1-3$ times & 3 & \\
$>2$ years & $4-7$ times & 3 & \\
\hline
\end{tabular}

\section{CONCLUSION}

Click ratio, click time, user experience, and Nolong,in utilization in terms of safety driving had successfully been measured in the testing phase. The result of click ratio is $90.91 \%$ and for click time is 1 
minute 27 seconds. Based on UEQ results show that community of GoJek Cikarang respond Nolong.in in a good way. There are also some suggestions for the development and future researches of Nolong.in: 1) Cooperation with police officers in order to help drivers when incident happened; 2) Cooperation with hospitals in order to help drivers that needs medical attention: 3) Can differentiate every incident that happened to driver, so that it can send notification based on incident's type.

\section{REFERENCES}

[1] A. Z. Jidin, et al., "Implementation of Algorithm for Vehicle Anti-Collision Alert System in FPGA," International Journal of Electrical and Computer Engineering (IJECE), vol.7, no.2, pp.775-783, 2017.

[2] V. K. Kiran, et al., "An Early Detection-Warning System to Identify Speed Breakers and Bumpy Roads using Sensors in Smartphones," International Journal of Electrical and Computer Engineering (IJECE), vol.7, no.3, pp.1377-1384, 2017.

[3] S. Sharma and D. Shah, "Real-Time Automatic Obstacle Detection and Alert System for Driver Assistance on Indian Roads," Indonesian Journal of Electrical Engineering and Computer Science (IJEECS), vol.1, no.3, pp.635646, 2016.

[4] S. S. R. Shariff, et al., "Determining Hotspots of Road Accidents Using Spatial Analysis," Indonesian Journal of Electrical Engineering and Computer Science (IJEECS), vol.9, no.1, pp.146-151, 2018.

[5] S. G. Fernandez, et al., "GPS \& GSM Based Accident Detection and Auto Intimation," Indonesian Journal of Electrical Engineering and Computer Science (IJEECS), vol.11, no.1, pp.336-361, 2018.

[6] T. Serre, et al., "Towards a Classification of Road Incidents Acquired from Public Fleets of Vehicles," in Proc. of Second International Symposium on Future Active Safety Technology: Toward Zero-Traffic-Accident (FASTzero'13), Japan, 2013.

[7] E. Gakis, et al., "Mining Traffic Data for Road Incidents Detection," in Proc. 2014 IEEE 17th International Conference on Intelligent Transportation Systems (ITSC), China: Qingdao, pp.930-935, 2014.

[8] F. Purba, 2017, "Tingkat Kriminalitas di Bekasi Tertinggi Se-Jawa Barat-The Highest Crime Rate in Bekasi in West Java". [Online]. Available: http://news.liputan6.com/read/2824102/tingkat-kriminalitas-di-bekasi-tertinggi-se-jawabarat

[9] Statistic Center-Badan Pusat Statistik Kota Bekasi, 2017, "Banyaknya Kejahatan di Kota Bekasi menurut Jenis Kejahatan-The number of crimes in the city of Bekasi according to the type of crime". [Online]. Available: https://bekasikota.bps.go.id/linkTabelStatis/view/id/23

[10] B. B. Gunawan, "Online Motorcycle Taxi Emergency and Accident Assisting Social IoT Platform," Thesis, Dept. Electrical Eng., President Univ., Bekasi, Indonesia, 2017.

[11] F. Gioachin, et al., "Emergency Alerts as RSS Feeds with Interdomain Authorization," in Proc. Second International Conference on Internet Monitoring and Protection (ICIMP), USA: San Jose, 2007.

[12] P. Bellini, et al., 2013, "Mobile Emergency, an Emergency Support System for Hospitals in Mobile Devices: Pilot Study". [Online]. Available: https://www.ncbi.nlm.nih.gov/pmc/articles/PMC3668604/

[13] Q. Liu, "The Usage of Microsoft Push Notification Service on Mobile Devices," Thesis, Dept. Information, Lappeenranta Univ., Lappeenranta, Finland, 2011.

[14] U. Acer, et al., (2015, Aug). "Energy Efficient Scheduling for Mobile Push Notification", in Proc. of MOBIQUITOUS'15, Portugal: Coimbra, pp.100-109, 2015

[15] J. Ding, et al., "An Approach for Modeling and Analyzing Mobile Push Notification Services," in Proc. of 2014 IEEE International Conference on Services Computing (SCC), USA: Anchorage, pp.725-732, 2014.

[16] K. W. Umbach, "What is 'Push Technology'?”, CRB Note, vol.4, no.6, pp.1-18, 1997.

[17] Firebase.google.com. "Firebase Cloud Messaging”. [Online]. Available: https://firebase.google.com/docs/cloudmessaging/.

[18] Developers.google.com. "Google Maps Distance Matrix API”. [Online]. Available: https://developers.google.com/maps/documentation/distance-matrix/start

[19] A. S. Shirazi, et al., "Large-scale Assessment of Mobile Notifications," in Proc. of the SIGCHI Conference on Human Factors in Computing Systems, Canada: Toronto, pp.3055-3064, 2014.

[20] J. Park, et al., "Developing Elements of User Experience for Mobile Phones and Services: Survey, Interview, and Observation Approaches," Human Factors and Ergonomics in Manufacturing \& Service Industries, vol.23, issue 4, pp.279-293, 2013.

[21] UEQ-Online, 2015, "Welcome to the User Experience Questionnaire (UEQ) A Questionnaire to Measure the UX". [Online]. Available: http://www.ueq-online.org

[22] B. Laugwitz, T. Held, and M. Schrepp, “Construction and Evaluation of a User Experience Questionnaire," Lecture Notes in Computer Science, vol.5298, pp.63-76, 2008.

[23] Sugiyono, Metode Penelitian Pendidikan: Pendekatan Kuantitatif, Kualitatif, dan R\&D-Educational Research Methods: Quantitative, Qualitative, and R\&D Approaches. Bandung: Alfabeta, 2010.

[24] H. B. Santoso, et al., "Measuring User Experience of the Student-Centered e-Learning Environment," The Journal of Educators Online, vol.13, no.1, pp.58-79, 2016.

[25] M. Schrepp, 2015, "User Experience Questionnaire Handbook". [Online]. Available: http://www.ueq-online.org. 